\title{
Elemental Sulfur Lowers Redox Potential and Produces Sulfide in Putting Green Sand
}

\author{
W.L. Berndt ${ }^{1}$ and J.M. Vargas, Jr. ${ }^{2}$ \\ 102 Pesticide Research Center, Michigan State University, East Lansing, \\ MI 48824
}

Additional index words. anaerobiosis, black layer, lactate, organic matter, sulfate,

sulfate-reducing bacteria, turfgrass

\begin{abstract}
Biological production of sulfide $\left(\mathrm{S}^{2-}\right)$ in soil has been reported to depend on system redox potential and on the concentrations of available sulfate $\left(\mathrm{SO}_{4}^{2-}\right)$ and organic carbon (OC). The purpose of this laboratory study was to determine whether elemental sulfur $\left(S^{\circ}\right)$ could influence redox potential and $S^{2-}$ production in sand used to construct putting greens. Treatment with $\mathrm{S}^{\mathbf{0}}$ depressed redox potential as pe $+\mathrm{pH}$, and stimulated accumulation of both free $\mathrm{H}_{2} \mathrm{~S}$ and acid-soluble $\mathrm{S}^{2-}$. Organic carbon as lactate $\left(\mathrm{C}_{3} \mathrm{H}_{5} \mathrm{O}_{3} \mathrm{Na}\right)$ intensified the effects of $\mathrm{S}^{\mathbf{0}}$, primarily by influencing $\mathrm{pH}$. Thus, $\mathrm{S}^{\mathbf{0}}$ application could induce anaerobiosis and subsequently affect turf quality by heightening production of free hydrogen sulfide $\left(\mathrm{H}_{2} \mathrm{~S}\right)$. It could also contribute to $\mathrm{S}^{2-}$ accumulation possibly expressed as a black layer or blackening of the root zone.
\end{abstract}

A black banding or blackening of the root zone, termed black layer, has been observed in the soil profile of sand putting greens by turfgrass practitioners (Berndt et al., 1987; Gockel, 1987; Hodges, 1987a, 1987b, 1989; Lubin, 1987; Rankin, 1988; Scott, 1986; Smith, 1988). A decline in the quality of turfgrass has frequently been associated with

Received for publication 11 Mar. 1992. Accepted for publication 1 July 1992. The cost of publishing this paper was defrayed in part by the payment of page charges. Under postal regulations, this paper therefore must be hereby marked advertisement solely to indicate this fact.

${ }^{1}$ Turfgrass Management Consultant, 6701 Mallards Cove Road, 18-G, Jupiter, FL 33458.

${ }^{2}$ Professor, Dept. of Botany and Plant Pathology and the Pesticide Research Center, Michigan State Univ., E. Lansing, MI 48824. the black layer (Berndt et al., 1987, 1989; Berndt and Vargas, 1989; Scott, 1986). We hypothesized that the black layer was an accumulation of precipitated sulfides $\left(\mathrm{S}^{2-}\right)$. We suggested that $\mathrm{S}^{2-}$ production could be stimulated by application of elemental sulfur $\left(S^{0}\right)$ during periods of anaerobiosis (Berndt et al., 1987, 1989; Berndt and Vargas, 1989). Further, we postulated that $S^{0}$ may contribute to anaerobiosis and that turf quality may decline due to occurrence of free hydrogen sulfide $\left(\mathrm{H}_{2} \mathrm{~S}\right)$, which is a known respiratory toxin (Atlas and Bartha, 1981). The objective of this research was to test the hypothesis that $\mathrm{S}^{\mathrm{O}}$ could decrease redox potential and stimulate $S^{2-}$ production in sands typically used to construct the root zone of golf putting greens.

For the experiment, $200 \mathrm{~g}$ sand was placed in 125-ml glass serum bottles. Sand particle size distribution was $99 \%$ of particles $>0.1$ $\mathrm{mm}$ in diameter and $84.5 \%$ of particles $>0.25$ $\mathrm{mm}$ in diameter, with $100 \%$ of particles $<1$ mm. Organic matter content was $0.0125 \%$ by weight. Particle distribution was determined by wet sieving and organic matter determined by loss on ignition. Sand bulk density was $\approx 2.2$ to $2.3 \mathrm{~g} \cdot \mathrm{cm}^{-3}$.

Dry sand in bottles was treated with flowable $52 \% \mathrm{~S}^{0}$ (Cleary Chemical, Somerset, N.J.) at rates of $0.0,73.2$, or $146.4 \mathrm{~kg} \mathrm{~S} \%$ ha, based on the exposed surface area of the sand inside the bottle. Cross-sectional area of the bottle was $\approx 30 \mathrm{~cm}^{2}$. Thus, $0.04 \mathrm{~g}$ material was directly applied for the $73.2-\mathrm{kg}$ rate. The $S^{o}$ rates were considered representative of rates conventionally applied in a turf management scheme.

After treatment with $\mathrm{S}^{\mathrm{O}}$, bottles were filled with either tap water, or organic carbon (OC) as sodium lactate $\left(\mathrm{C}_{3} \mathrm{H}_{5} \mathrm{O}_{3} \mathrm{Na}\right)$ solution to exclude gaseous head space. Lactate solution was prepared as either 112 or $1120 \mathrm{mg}$ lactate $/ \mathrm{kg}$ water. The precise volume of water or lactate solution added to each bottle was unknown but was estimated to be near 35 $\mathrm{ml}$. Thus, $\approx 13.3$ or $133.3 \mathrm{~kg}$ lactate/ha was directly applied based on exposed surface area. Tap water or lactate solution within bottles was considered experimental solution, as $\approx 20$ to $30 \mathrm{ml}$ remained above the sand surface at all times as overlying water. Excess experimental solution was needed to facilitate measurement of dissolved and precipitated $\mathrm{S}^{2-}$. Sulfate content of the tap water was $30 \mu \mathrm{g} \cdot \mathrm{ml}^{-1}$ as measured by low-pressure liquid anion chromatography.

After being filled completely, units were sealed with butyl rubber stoppers, crimped with aluminum seals, then incubated at $30 \mathrm{C}$ for 21 days in darkness. A syringe needle stuck through the stopper served as a fluid vent to accommodate sealing. The design was completely randomized with three replications. Treatments were arranged factorially. 
Table 1. Influence of lactate and elemental sulfur on redox parameters and sulfur compounds in sand. Experimental units were incubated at $30 \mathrm{C}$ in darkness for 21 days. Values are means of three replications.

\begin{tabular}{|c|c|c|c|c|c|c|c|}
\hline \multicolumn{2}{|c|}{$\begin{array}{l}\text { Treatments } \\
\left(\mathrm{kg} \cdot \mathrm{ha}^{-1}\right)\end{array}$} & \multicolumn{3}{|c|}{ Redox parameters } & \multicolumn{3}{|c|}{$\begin{array}{l}\text { Sulfur compounds } \\
\left(\mathrm{mg} \cdot \mathrm{kg}^{-1}\right)\end{array}$} \\
\hline Lactate & $\overline{\text { Sulfur }}$ & $\mathrm{pe}^{y}$ & $\mathrm{pe}+\mathrm{pH}$ & $\mathrm{pH}$ & $\mathrm{H}_{2} \mathrm{~S}$ & $\mathrm{AS}^{2-}$ & $\mathrm{SO}_{4}^{2-}$ \\
\hline$\overline{0.0}$ & $\begin{array}{r}0.0 \\
73.2 \\
146.4\end{array}$ & $\begin{array}{l}-0.5 \\
-2.2 \\
-2.1\end{array}$ & $\begin{array}{l}6.9 \\
4.8 \\
4.8\end{array}$ & $\begin{array}{l}7.4 \\
7.0 \\
6.9\end{array}$ & $\begin{array}{l}0.0 \\
4.2 \\
3.8\end{array}$ & $\begin{array}{r}5.1 \\
46.7 \\
60.2\end{array}$ & $\begin{array}{l}19.1 \\
27.4 \\
33.6\end{array}$ \\
\hline 13.3 & $\begin{array}{r}0.0 \\
73.2 \\
146.4\end{array}$ & $\begin{array}{l}-0.8 \\
-2.2 \\
-2.3\end{array}$ & $\begin{array}{l}6.5 \\
4.7 \\
4.4\end{array}$ & $\begin{array}{l}7.3 \\
6.9 \\
6.7\end{array}$ & $\begin{array}{r}0.0 \\
5.2 \\
18.3\end{array}$ & $\begin{array}{r}5.1 \\
74.8 \\
65.5\end{array}$ & $\begin{array}{r}3.7 \\
28.8 \\
34.4\end{array}$ \\
\hline 133 & $\begin{array}{r}0.0 \\
73.2 \\
146.4\end{array}$ & $\begin{array}{l}-0.8 \\
-1.8 \\
-2.6\end{array}$ & $\begin{array}{l}6.2 \\
5.0 \\
4.0\end{array}$ & $\begin{array}{l}7.0 \\
6.8 \\
6.6\end{array}$ & $\begin{array}{r}0.7 \\
2.7 \\
31.2\end{array}$ & $\begin{array}{r}6.1 \\
86.7 \\
99.7\end{array}$ & $\begin{array}{r}1.1 \\
22.5 \\
34.6\end{array}$ \\
\hline $\mathrm{LSD}_{P}=$ & & 0.6 & 0.6 & 0.05 & 9.1 & 17.7 & 4.9 \\
\hline
\end{tabular}

${ }^{2}$ Measured concentration of sulfide as free hydrogen sulfide $\left(\mathrm{H}_{2} \mathrm{~S}\right)$ or acid-soluble sulfide $\left(\mathrm{AS}^{2-}\right)$ or measured concentration of sulfate $\left(\mathrm{SO}_{4}^{2}\right)$ in experimental solution.

${ }^{y} \mathrm{pe}=\operatorname{Eh}(59.2)$ where Eh $=$ half-cell potential for $\mathrm{H}_{2}$.

After incubation, experimental solution from each unit was sampled for $\mathrm{H}_{2} \mathrm{~S}$ and $\mathrm{SO}_{4}^{2-}$. For this sampling, $2 \mathrm{ml}$ of solution was extracted from each closed vessel with a S-ml syringe equipped with a $0.22-\mu \mathrm{m}$ syringe filter. Injecting $2.5 \mathrm{ml}$ of $\mathrm{O}_{2}$-free $\mathrm{N}_{2}$ (Macy et al., 1972) into each closed unit with a second syringe forced the sample solution into the receptor syringe. Thus, filtered sample from each experimental unit was withdrawn from completely filled vessels without contact with atmospheric $\mathrm{O}_{2}$ or interference from sand debris.

Subsamples of $0.4 \mathrm{ml}$ were then subsequently drawn from the original receptor syringe with a 1-ml tuberculin syringe that was previously flushed with $\mathrm{O}_{2}$-free $\mathrm{N}_{2}$. To measure $\mathrm{H}_{2} \mathrm{~S}$, the 0.4-ml subsample was injected into $4 \mathrm{ml}$ moving $\mathrm{HCl}: \mathrm{CuSO}_{4}$ reagent in a 10-ml spectrophotometer cuvette according to the method of Cord-Ruwisch (1985). Solution was moved in the cuvette by using a magnetic spin bar and magnetic stir plate. Absorbance was immediately determined in a spectrophotometer at $480 \mathrm{~nm}$. Reagent without sample served as a blank. The AA between blanks and water at $480 \mathrm{~nm}$ was zero. A calibration curve made with dilutions of sodium sulfide $\left(\mathrm{Na}_{2} \mathrm{~S}\right)$ served as a $\mathrm{S}^{2-}$ concentration reference. Sample $\mathrm{SO}_{4}^{2-}$ concentration was measured with remaining sample using low-pressure liquid anion chromatography.

Next, the crimp seals and butyl stoppers were removed under a constant stream of $\mathrm{O}_{2^{-}}$ free $\mathrm{N}_{2}$ (Macy et al., 1972) and the pe + $\mathrm{pH}$ (Lindsay, 1979) of remaining solution was determined. Hydrogen ion concentration was measured with a $\mathrm{Ag} / \mathrm{AgCl}$ combination electrode, and pe was determined using a $\mathrm{Pt}$ redox electrode with a calomel reference. The term pe $=\operatorname{Eh}(59.2)$, where $\mathrm{Eh}=$ half cell potential for $\mathrm{H}_{2}$. Addition of pe and $\mathrm{pH}$ constitutes a modem indication of redox potential, and both parameters are necessary to specify the redox status of aqueous environments (Lindsay, 1979).

Finally, freshly boiled tap water cooled under $\mathrm{O}_{2}$-free $\mathrm{N}_{2}$ was added to each bottle to refill completely. The butyl stoppers were then replaced and recrimped; a syringe needle attached to a closed S-ml syringe was used as a fluid vent. Next, $2 \mathrm{ml}$ freshly boiled $37 \% \mathrm{HCl}$ cooled under $\mathrm{O}_{2}$-free $\mathrm{N}_{2}$ was injected into each unit, again using the syringe assembly as a fluid vent. Vents were removed, then units were inverted several times to ensure soil contact with acidic experimental solution. The $\mathrm{HCl}$ volatilized any acidsoluble $S^{2-}$ that had accumulated. Samples of experimental solution were then subsequently measured for $\mathrm{H}_{2} \mathrm{~S}$ colorimetrically via the method of Cord-Ruwisch (1985). This procedure in effect gave a measure of acidsoluble $\mathrm{S}^{2-}$ that had accumulated as a precipitate.

Sand in certain units had darkened by 21 days. The sand appeared to be darker where $S^{0}$ or $S^{0}$ plus lactate was added. Increasing the level of $S^{0}$ or $S^{0}$ plus lactate intensified the darkening. The observed darkening was assumed to be due to accumulation of acidsoluble $\mathrm{S}^{2-}$, possibly as FeS or $\mathrm{MnS}$, which are known to be black (Atlas and Bartha, 1981). However, such was not proven in this study.

Treatment with $S^{0}$ depressed $(P<0.01)$ redox potential as pe $+\mathrm{pH}$ in sand by lowering both pe and $\mathrm{pH}$ (Tables 1 and 2). Depression of $\mathrm{pe}+\mathrm{pH}$ by treatment with $S^{0}$ probably involved the microbial oxidation of $\mathrm{S}^{0}$ to $\mathrm{SO}_{4}^{2-}$ :

$$
\mathrm{S}^{0}+3 / 2 \mathrm{O}_{2}+\mathrm{H}_{2} \mathrm{O}<\longrightarrow \mathrm{H}_{2} \mathrm{SO}_{4}
$$

This process should consume $\mathrm{O}_{2}$ and increase $[\mathrm{H+}$, thereby reducing redox potential. When $\mathrm{O}_{2}$ in soils is depleted, microbial activity would be expected to release electrons (e-) to the environment, thus reducing the value of pe (Lindsay, 1979). The resulting decrease in $\mathrm{pH}$ due to increasing $[\mathrm{H}+]$ would also force a mathematical reduction in redox potential.

Lactate tended to depress pe $+\mathrm{pH}$ but to a much lesser extent than $S^{0}$ (Tables 1 and 2). This effect resulted primarily from a lowering of $\mathrm{pH}$, as no lactate effect on pe or pe $+\mathrm{pH}$ was detected by analysis of variance. The effect on $\mathrm{pH}$ was probably due to acid production associated with degradation of the lactate. Lactate could have also increased bacterial respiration rates enhancing 0 , consumption. Such does not seem unreasonable in our study, as experimental units were sealed, and $\mathrm{O}_{2}$ diffusion was stopped. However, we did not measure $\mathrm{O}_{2}$ consumption.

Treatment with $\mathrm{S}^{0}$ resulted in free $\mathrm{H}_{2} \mathrm{~S}$ becoming detectable and also resulted in the pronounced accumulation of acid-soluble $\mathrm{S}^{2-}$ (Table 1). Treatment with lactate had a much smaller effect. Lactate $\times S^{0}$ interactions were detected. The effect of adding lactate was to intensify the effect of $S^{0}$ in producing both $\mathrm{H}_{2} \mathrm{~S}$ and acid-soluble $\mathrm{S}^{2-}$. Accumulation of

Table 2. Analysis of variance summary describing the influence of sulfur and lactate on redox parameters and sulfur compounds in sand. Main effect sum of squares were partitioned into linear or quadratic components.

\begin{tabular}{|c|c|c|c|c|c|c|c|}
\hline \multirow[b]{3}{*}{ Source } & \multirow[b]{3}{*}{ df } & \multicolumn{6}{|c|}{$\mathrm{F}$ values } \\
\hline & & \multicolumn{3}{|c|}{ Redox parameters } & \multicolumn{3}{|c|}{ Sulfur compounds ${ }^{z}$} \\
\hline & & $\mathrm{pe}^{\mathrm{y}}$ & $\mathrm{pe}+\mathrm{pH}$ & $\mathrm{pH}$ & $\mathrm{H}_{2} \mathrm{~S}$ & $\mathrm{AS}^{2-}$ & $\mathrm{SO}_{4}^{2-}$ \\
\hline $\begin{array}{l}\text { Reps } \\
\text { Sulfur } \\
\text { Linear } \\
\text { Quadratic }\end{array}$ & $\begin{array}{l}2 \\
2 \\
1 \\
1\end{array}$ & $\begin{array}{l}54.9^{* *} \\
94.2^{* *} \\
15.2^{* *}\end{array}$ & $\begin{array}{r}90.1^{* * *} \\
157.6^{* *} \\
22.8^{* *}\end{array}$ & $\begin{array}{r}726.8^{* *} \\
1057.0^{* *} \\
101.0^{* *}\end{array}$ & $\begin{array}{c}27.2^{* *} \\
49.2^{* *} \\
5.3^{*}\end{array}$ & $\begin{array}{r}126.8^{* *} \\
205.8^{* *} \\
47.9^{* *}\end{array}$ & $\begin{array}{r}193.4^{* *} \\
368.4^{* *} \\
18.7^{* *}\end{array}$ \\
\hline $\begin{array}{l}\text { Lactate } \\
\text { Linear } \\
\text { Quadratic }\end{array}$ & $\begin{array}{l}2 \\
1 \\
1\end{array}$ & $\begin{aligned} & 0.5^{\mathrm{NS}} \\
< & 1^{\mathrm{NS}} \\
< & 1^{\mathrm{NS}}\end{aligned}$ & $\begin{aligned} & 3.2^{\mathrm{NS}} \\
& 6.0^{*} \\
< & 1^{\mathrm{NS}}\end{aligned}$ & $\begin{array}{c}248.3^{* *} \\
392.0^{* *} \\
2.0^{\text {NS }}\end{array}$ & $\begin{array}{l}6.4^{* *} \\
12.7^{* *} \\
<1^{\mathrm{NS}}\end{array}$ & $\begin{array}{l}15.4^{* *} \\
30.5^{* * *} \\
<1^{\mathrm{NS}}\end{array}$ & $\begin{array}{l}14.3^{* *} \\
28.1^{* *} \\
<1^{\mathrm{NS}}\end{array}$ \\
\hline$S \times L$ & 4 & $1.6^{\mathrm{NS}}$ & $2.1^{\mathrm{NS}}$ & $11.5^{* *}$ & $6.9 * *$ & $4.8^{* *}$ & $11.7^{* *}$ \\
\hline Error & 16 & & & & & & \\
\hline
\end{tabular}

${ }^{2} \mathrm{H}_{2} \mathrm{~S}$ denotes free hydrogen sulfide and $\mathrm{AS}^{2-}$ denotes acid-soluble sulfide. ${ }^{y} \mathrm{pe}=\mathrm{Eh}(59.2)$ where $\mathrm{Eh}=$ half-cell potential of $\mathrm{H}_{2}$.

NS,*,**Nonsignificant or significant at $P=0.05$ and $=0.01$, respectively. 
$\mathrm{S}^{2-}$ in this study probably occurred because $\mathrm{S}^{\mathrm{O}}$ or $\mathrm{SO}_{4}^{2-}$ was available to be reduced, adequate reducing equivalents were available, and anaerobiosis was induced. Sulfate or $\mathrm{S}^{\circ}$ reducing organisms were probably also present, but their populations were not documented. We assumed that the production of $\mathrm{S}^{2-}$ was biological in origin.

The results of this study show that adding $\mathrm{S}^{\mathrm{O}}$ to sand depresses redox potential and stimulates production of $\mathrm{H}_{2} \mathrm{~S}$ and acid-soluble $\mathrm{S}^{2-}$, especially when OC is abundant. Thus, in sand-based golf greens where $S^{0}$ is applied, there is potential for inducement of anaerobiosis and subsequent production of free $\mathrm{H}_{2} \mathrm{~S}$ or acid-soluble $\mathrm{S}^{2-}$. Since $\mathrm{H}_{2} \mathrm{~S}$ is a known e- transport inhibitor (Atlas and Bartha, 1981), $\mathrm{S}^{\mathrm{O}}$ addition could contribute to a decline in turf quality. Accumulation of acidsoluble $S^{2-}$ due to application of $S^{0}$ is also consistent with the idea of black layer development as a blackening of the root zone.

\section{Literature Cited}

Atlas, R.M. and R. Bartha. 1981. Microbial ecology: Fundamentals and applications. AddisonWesly, Reading, Mass.

Berndt, L. and J. Vargas. 1989. Sulfur, organic matter, and the black layer: Part II. Golf Course Mgmnt. 57(6):80-83.

Berndt, W.L. and J.M. Vargas, Jr. 1987. Etiology and impact of dissimilatory sulfate reduction in highly maintained turfgrass soils. Phytopathology 77(12):1716.

Berndt, W.L., J.M. Vargas, Jr., A.R. Detweiler, P.E. Rieke, and B.E. Branham. 1987. Black layer formation in highly maintained turfgrass soils. Golf Course Mgmnt. 55(6):106-112.

Berndt, L., J. Vargas, Jr, and B. Melvin. 1989. Sulfur, organic matter and black layer. Golf Course Mgmnt. 57(3):80-84.

Cord-Ruwisch, R. 1985. A quick method for the determination of dissolved and precipitated sulfides in cultures of sulfate-reducing bacteria. Microbial Methods 4:33-36.

Gockel, J. 1987. Looking for light in all the right places. Golf Course Mgmnt. .55(7):26-32.

Hodges, C.F. 1987a. Bluegreen algae and black layer: Part I. Landscape Mgmnt. 26(10):38-44.

Hodges, C.F. 1987b. Bluegreen algae and black layer: Part II. Landscape Mgmnt. 26(11):3031.

Hodges, C.F. 1989. Another look at black layer. Golf Course Mgmnt. 57(3):54-58.

Lindsay, W.L. 1979. Chemical equilibria in soils. Wiley, New York.

Lubin, T. 1987. One western view of black-layerlike problems. Golf Course Mgmnt. 55(5):7480.

Macy, J.M., J.E. Snellen, and R.E. Hungate. 1972. Use of syringe methods for anaerobiosis. Amer. J. Clinical Nutr. 25:1318-1323.

Rankin, P.C. 1988. When the black layer hit the fan. Turf Craft Austral. 6:18-20.

Scott, J.L. 1986. The black plague. Golf Course Mgmnt. 54(11):58-64.

Smith, J.D. 1988. Black plug layer on Saskatchewan golf courses. Greenmaster 24(8):6-21. 